\title{
Possibility on Ensuring the Health and Safety of Agricultural Workers: An Analysis Based on Field Study in Turkey
}

\author{
Hasan Parça ${ }^{1}$, Bülent Gülçubuk ${ }^{2, *}$ \\ ${ }^{1}$ Graduate School of Natural and Applied Sciences, Ankara University, Turkey \\ ${ }^{2}$ Department of Agricultural Economics, Faculty of Agriculture, Ankara University, Turkey
}

Received June 27, 2020; Revised August 20, 2020; Accepted September 11, 2020

\section{Cite This Paper in the following Citation Styles}

(a): [1] Hasan Parça, Bülent Gülçubuk, "Possibility on Ensuring the Health and Safety of Agricultural Workers: An Analysis Based on Field Study in Turkey," Universal Journal of Agricultural Research, Vol. 8, No. 5, pp. 173 - 183, 2020. DOI: 10.13189/ujar.2020.080505.

(b): Hasan Parça, Bülent Gülçubuk (2020). Possibility on Ensuring the Health and Safety of Agricultural Workers: An Analysis Based on Field Study in Turkey. Universal Journal of Agricultural Research, 8(5), 173 - 183. DOI: 10.13189/ujar.2020.080505.

Copyright $\bigcirc 2020$ by authors, all rights reserved. Authors agree that this article remains permanently open access under the terms of the Creative Commons Attribution License 4.0 International License

\begin{abstract}
The sector of agriculture is marked by a wide range of activities involving high risks, and this fact is relevant to all parties who are related to this sector in some way. Most agricultural activities that take place outdoors are susceptible to natural disasters at any time. This is a permanent threat to safety and health of people working in agriculture. The Turkish Law No. 6331 on Work Health and Safety covers all sectors where enterprises employ one or more persons. Still, there are significant difficulties in applying the law to the sector of agriculture. The main reason is the high incidence of informal employment including women and children. In 2019, for example, $86.6 \%$ of total labor force in agriculture was in informal status. While the rate is 79.1 for males, it is much higher 96.3 for females. These are figures much above the case in other sectors. It also means that people working in agriculture are excluded from social security schemes and without protection in terms of work safety and health. The present article presents and discusses the findings of a field study on the level of perception related to work health and safety of farmers (51 farmers) engaged in crop farming in Beypazarı , a district of Ankara Province. It also deals with how the "Work Health and Safety Law" is translated into practice, examines the socioeconomic status of farmers on the basis of questionnaires administered and investigates the farmers' perception safety and health along with the activities they consider risky.
\end{abstract}

Keywords Law No.6331, Work Health and Safety, Agricultural Employment, Agricultural Sector, Agricultural Labor, Turkey-Ankara

\section{Introduction}

Agriculture is a sector in Turkey with its economic and social place in various respects. It can be said that control over agricultural production is more limited than it is in other sectors. Since agricultural production is susceptible to climatic and natural factors, those who work in this sector are confronted with various hazards. The situation in agriculture emerges, besides depending on natural conditions, as a result of some accompanying factors including seasonality, weight of unpaid family labor, low level of education and income instability. Hence, while having its vital importance for all, the concept of social security gains further importance for agriculture and families active in this sector. In spite of this, workforce in agriculture is the last segment to integrate into a social security scheme in Turkey as it is the case in all other countries. $(7,13)$.

Though many activities in both crop farming and stock-breeding are considered as hazardous, obligations deriving from the Law No. 6331 are not fulfilled in Turkish 
agriculture. It is said that the main reason is the informal structure of this sector and the fact that the majority consists of small family farms active on their own account. However, potential hazards and risks in this sector may affect not only those directly engaged in farming activities but other citizens in the country as well. It is, therefore, necessary to raise the level of awareness and perception about these risks and hazards in the context of work health and safety (WHS) and adopt necessary measures within the framework of a plan.

According to the 2016/2017 season Farmer registry System data, 1,051 farmers are engaged in vegetable culture on 50,358 decares of land in Beypazarı District. 55 of these farmers practice vegetable culture on land larger than 150 decares. Their total culture land adds up to 13,500 decares, which constitute $27.1 \%$ of total vegetable culture area. These are the farmers who employ the highest number of agricultural workers. Assuming data needed for WHS from the point of employers and workers in open field culture could be obtained this way, 51 out of these 55 farmers who accepted were interviewed face-to-face.

\subsection{Agricultural Sector in Terms of Work Accidents}

There are over 570 million farmers and at least 500 million family farms in the world. In proportional terms, $90 \%$ of all farms are family farms (15). Further, family farms command the large part of culture land and account for $80 \%$ of agricultural output. Agriculture is one of the most hazardous sectors in terms of work accidents and other risks. According to 2011 data by the United Nations Food and Agriculture Organization, there are 1.3 billion people worldwide working in agriculture. The 2015 report of the ILO indicates that the share of agriculture in global employment fell from $40.5 \%$ in 2010 to $37.5 \%$ in 2014 . (15)

In Europe, 97\% of 12.2 million farms are family farms. Data from 2013 agriculture survey says 22.2 million people regularly work in this sector. 20.2 million of these totals are either farm owners or their family members (8). Agriculture is considered as to be among the most hazardous sectors in terms of working conditions. According to 2017 work accident statistics covering EU-28 countries, $4.7 \%$ of non-fatal and $12.8 \%$ of fatal work accidents take place in the sector of agriculture, forestry and fishing. With these figures, agriculture comes after the sectors of construction, manufacturing and logistics (Figure 1.).

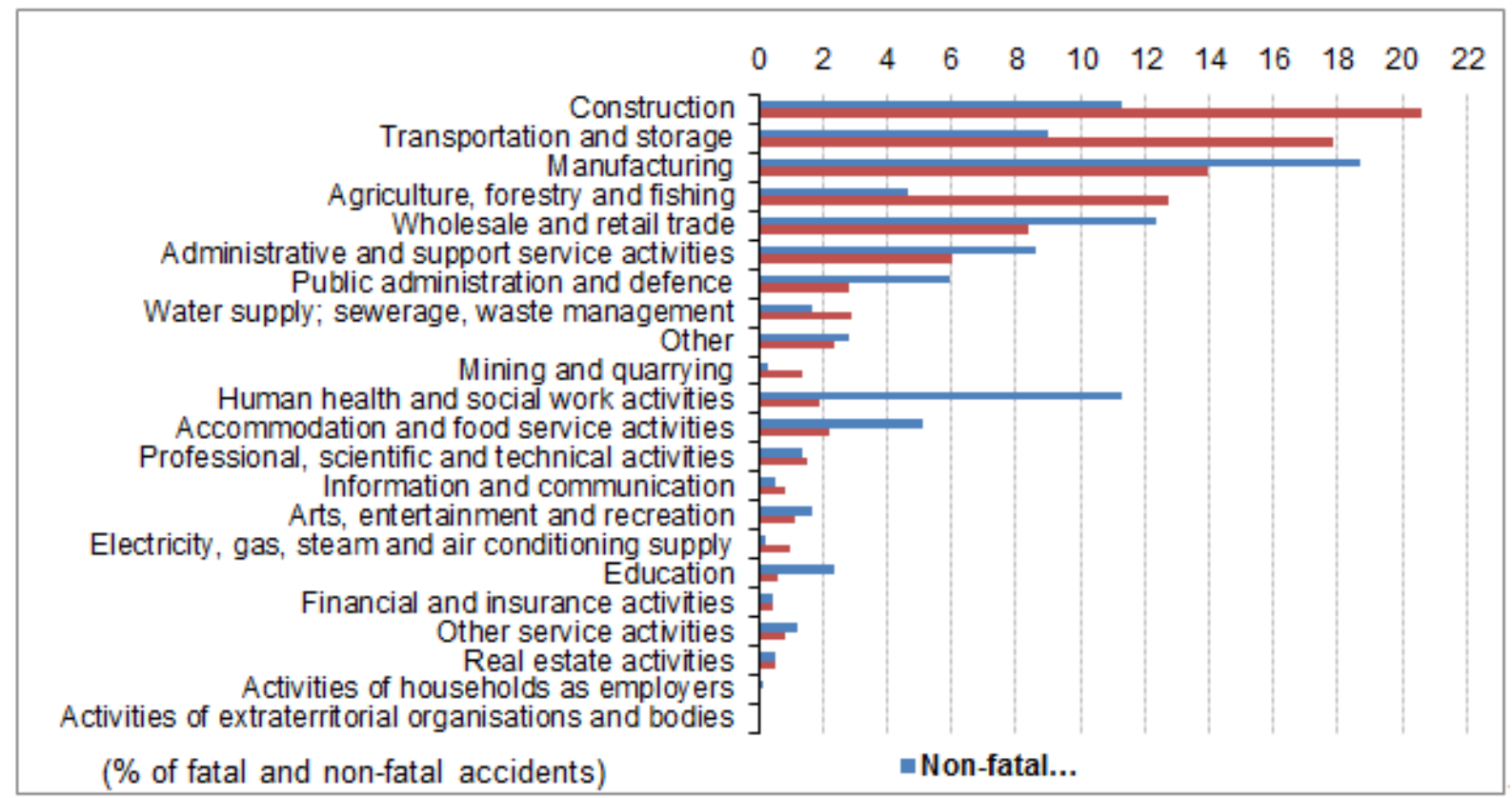

Figure 1. Fatal and non-fatal accidents at work by NACE section, EU-28, 2017 (EUROSTAT 2019)* 
Table 1. Basic labor force status of people in agricultural sector (18)

\begin{tabular}{|c|c|c|c|c|c|c|c|c|c|c|}
\hline \multirow{3}{*}{ Employment status } & \multicolumn{6}{|c|}{ Total } & \multirow{2}{*}{\multicolumn{2}{|c|}{$\begin{array}{c}\text { Male } \\
\text { Unregistered } \\
\text { rate (\%) } \\
\end{array}$}} & \multirow{2}{*}{\multicolumn{2}{|c|}{$\begin{array}{c}\text { Female } \\
\text { Unregistered } \\
\text { rate (\%) } \\
\end{array}$}} \\
\hline & \multicolumn{2}{|c|}{$\begin{array}{c}\text { Employment } \\
(000)\end{array}$} & \multicolumn{2}{|c|}{$\begin{array}{c}\text { Unregistered } \\
(\mathbf{0 0 0 )}\end{array}$} & \multicolumn{2}{|c|}{$\begin{array}{c}\text { Unregistered } \\
\text { rate }(\%)\end{array}$} & & & & \\
\hline & 2018 & 2019 & 2018 & 2019 & 2018 & 2019 & 2018 & 2019 & 2018 & 2019 \\
\hline Total & 28.314 & 28.169 & 9.520 & 9.521 & 33,6 & 33,8 & 30,2 & 30,4 & 41,0 & 41,3 \\
\hline Regular or casual employee & 19.466 & 19.543 & 3.533 & 3.384 & 18,1 & 17,3 & 17,7 & 16,4 & 19,2 & 19,4 \\
\hline Employer & 1.288 & 1.264 & 300 & 399 & 23,3 & 31,6 & 24,2 & 33,0 & 15,0 & 20,4 \\
\hline Self employed & 4.752 & 4.605 & 3.161 & 3.180 & 66,5 & 69,1 & 62,9 & 66,7 & 83,8 & 80,8 \\
\hline Unpaid family worker & 2.807 & 2.758 & 2.525 & 2.558 & 90,0 & 92,7 & 88,0 & 89,3 & 90,7 & 94,2 \\
\hline Agriculture & 5.023 & 4.876 & 4.206 & 4.221 & 83,7 & 86,6 & 76,9 & 79,1 & 92,7 & 96,3 \\
\hline Regular or casual employee & 525 & 498 & 400 & 377 & 76,2 & 75,7 & 72,0 & 70,3 & 83,0 & 85,4 \\
\hline Employer & 51 & 38 & 27 & 21 & 52,9 & 55,3 & 50,0 & 50,0 & 100,0 & 100,0 \\
\hline Self employed & 2.187 & 2.116 & 1.686 & 1.682 & 77,1 & 79,5 & 75,1 & 77,8 & 94,0 & 93,8 \\
\hline Unpaid family worker & 2.260 & 2.225 & 2.093 & 2.141 & 92,6 & 96,2 & 89,1 & 90,9 & 93,6 & 97,8 \\
\hline Non-agricultural & 23.290 & 23.292 & 5.314 & 5.300 & 22,8 & 22,8 & 22,2 & 22,3 & 24,3 & 24,0 \\
\hline Regular or casual employee & 18.941 & 19.045 & 3.133 & 3.007 & 16,5 & 15,8 & 16,3 & 15,1 & 17,0 & 17,4 \\
\hline Employer & 1.237 & 1.225 & 273 & 378 & 22,1 & 30,9 & 23,1 & 32,5 & 14,4 & 18,1 \\
\hline Self employed & 2.565 & 2.489 & 1.475 & 1.498 & 57,5 & 60,2 & 51,0 & 55,9 & 79,7 & 75,5 \\
\hline Unpaid family worker & 547 & 533 & 432 & 417 & 79,0 & 78,2 & 85,9 & 86,3 & 70,4 & 69,0 \\
\hline
\end{tabular}

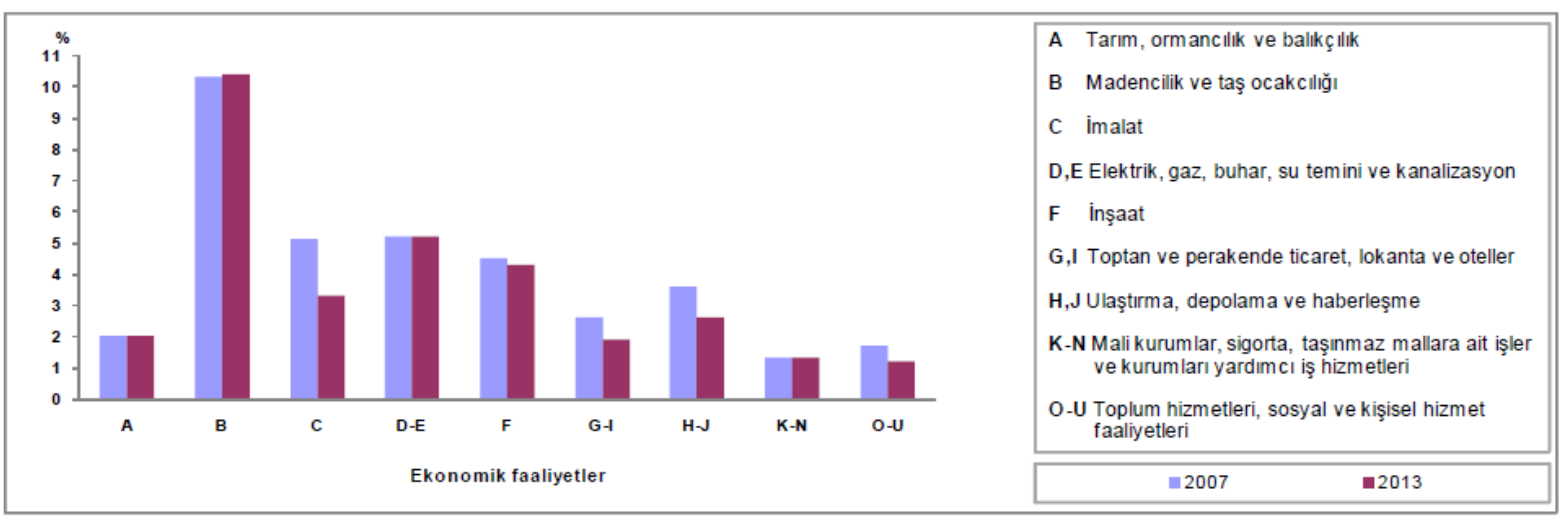

Figure 2. Rate of experiencing work accident by sectors, 2007- 2013 (TÜIK-2013)

Informal employment is the most important problem for those working in agriculture. Being informally employed, many people remain out of the coverage of social security. Table 1 shows $86.6 \%$ of total labor force in agriculture are in informal status. The rate is 79.1 for males and $96.3 \%$ for females. These are figures of informal employment far above the one we can find in other sectors. It is clear that people in the agricultural sector are disadvantaged in this respect.

According to unofficial statistical information collected by the Work Health and Safety Assembly for the year 2019, 442 out of 1,736 cases of death took place in the sector of agriculture/forestry. This means $25.46 \%$ of work accident mortality is related to agricultural activities (Table 2.). These statistics confirm that agriculture as a sector is as important as other sectors in terms of work health and safety.

Table 2. Rates of mortality by branches (18)

\begin{tabular}{|l|c|c|}
\hline By branches of economic activity & Worker deaths & $\mathbf{\%}$ \\
\hline Agriculture/Forestry & $\mathbf{4 4 2}$ & $\mathbf{2 5 . 4 6}$ \\
\hline Construction & 336 & 19.35 \\
\hline Transportation & 234 & 13.48 \\
\hline Municipal/General Works & 105 & 6.05 \\
\hline Commerce/Office Works & 104 & 5.99 \\
\hline Metal & 70 & 4.03 \\
\hline Other sectors & 445 & 25.63 \\
\hline Total & 1.736 & 100.00 \\
\hline
\end{tabular}

According to work accident data by sectors as given by the TÜIK, agriculture in Turkey ranks $7^{\text {th }}$ in this respect, which is contrary to the world statistics (Figure 2.) This 
contrast of Turkey in relation to work accidents in agriculture can be explained by "informality, obscure

\subsection{Work Health and Safety in Turkish Agriculture}

Until 30 June 2012, WHS related provisions of the Labor Code No. 4857 (1) were applied to enterprises in agriculture and forestry where more than 50 workers were employed on contractual basis. The "Work Health and Safety Law" No. 6331 enacted in 2012, on the other hand, covers all branches where there is more than 1 person employed. Even though having one or more employees bring an enterprise under the scrutiny of the Law No. 6331 on "Work Health and Safety", some exceptions were introduced, leaving some farmers out of scope. Family farmers are excluded while defined as "Those producing goods and services on their own account without employing any other person. "Taking Turkish agriculture, we see the dominant part as small family farms based on unpaid family labor. $(2,4)$.

Agricultural production is generally considered among hazardous activities. In both crop farming and stock-breeding, although almost all activities are classified as hazardous, none of the obligations introduced by the relevant legislation can actually be implemented to eliminate risks and adopt necessary measures. Once " Those producing goods and services on their own account without employing any other person" are left out, accidents in this sector also remain out of the scope of the Law No. 6331.

\section{Material and Methods}

\subsection{Material}

The District of Beypazarı has its significant place in crop farming in Turkey, and it is the leading one in some crops. According to TÜİK's 2017 crop farming statistics, Beypazar1 accounts for $14.4 \%$ of green onion, $22.1 \%$ of carrot, $14.3 \%$ of lettuce and $13.5 \%$ of spinach production in Turkey. These figures point to the prominent place of Beypazar1 in vegetable culture in the country. Vegetable farming is also the branch in crop culture that requires labor beyond family labor more than any other branch $(17,10)$. The primary material of this study is the questionnaires applied face-to-face to farmers. The secondary material comprises legislative arrangements, reports, earlier studies about the topic and related statistics.

\subsection{Methodology}

According to 2016/2017 agricultural season Farmer Registry System, 1,051 farmers are engaged in vegetable causes of death and non-reporting of cases.”

culture on 50,358 decares of land in Beypazar1 district. 55 of these farmers have vegetable culture land larger than 150 decares. Their plots add up to 13,500 decares and these farmers account for $27.1 \%$ of total vegetable output of the district. They are also the largest labor force and agricultural worker users. 4 of the selected farmers did not want to respond to the questionnaire. The questionnaire was administered face-to-face to 51 farmers.

\section{Findings}

An important demographic factor examined in the study is the educational status of the family members of farmers over the age of 6. Examining the relationship between the level of education and gender, we find a statistically significant difference because of $\mathrm{P}=0.0136<0.05$. Males' level of education is higher than that of the females at high school and college/university level (Table 3.)

Table 3. Education level of family members of farmers covered by gender

\begin{tabular}{|c|c|c|c|c|c|}
\hline \multirow{2}{*}{\multicolumn{3}{|c|}{$\begin{array}{c}\text { Education levels and corresponding } \\
\text { rates }\end{array}$}} & \multicolumn{2}{|c|}{ Gender } & \multirow{3}{*}{$\begin{array}{c}\text { Total } \\
79\end{array}$} \\
\hline & & & \multirow{2}{*}{$\frac{\text { Male }}{34}$} & \multirow{2}{*}{$\begin{array}{c}\text { Female } \\
45\end{array}$} & \\
\hline \multirow{12}{*}{$\begin{array}{l}\text { Education } \\
\text { Level }\end{array}$} & \multirow{3}{*}{ Primary } & No. & & & \\
\hline & & $\%$ & 43 & 57 & 100 \\
\hline & & Total \% & 16.8 & 22.3 & 39,1 \\
\hline & \multirow{3}{*}{ Secondary } & No. & 23 & 13 & 36 \\
\hline & & $\%$ & 63.9 & 36.1 & 100 \\
\hline & & Total \% & 11.4 & 6.4 & 17,8 \\
\hline & \multirow{3}{*}{ High School } & No. & 32 & 27 & 59 \\
\hline & & $\%$ & 54.2 & 45.8 & 100 \\
\hline & & Total \% & 15.8 & 13.4 & 29,2 \\
\hline & \multirow{3}{*}{ College-University } & No. & 17 & 11 & 28 \\
\hline & & $\%$ & 60.7 & 39.3 & 100 \\
\hline & & Total \% & 8.4 & 5.4 & 13,9 \\
\hline \multirow{2}{*}{\multicolumn{2}{|c|}{ Total }} & No. & 106 & 96 & 202 \\
\hline & & $\%$ & 52,5 & 47.5 & 100 \\
\hline \multicolumn{6}{|c|}{ P:0,136 } \\
\hline
\end{tabular}

Ho: Education level does not vary by gender

According to chi-square test applied to examine the relationship between the change in the roles of family members and nature of works they perform, again there is statistically significant difference suggesting that as these roles change, works performed by family members also change (Table 4-Figure 3.). 


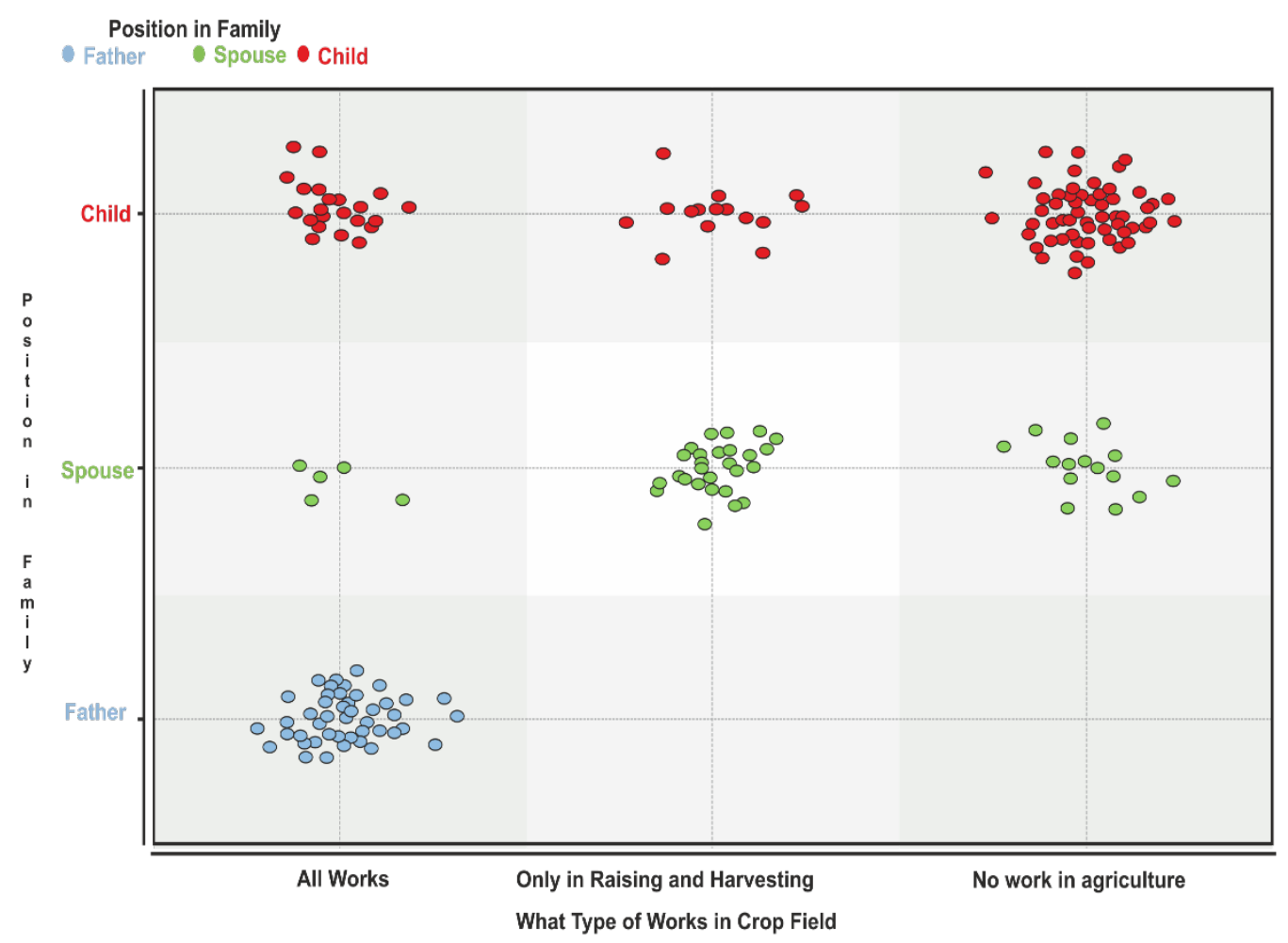

Figure 3. Family members' state of working in agriculture

Table 4. Family members' state of working in agriculture

\begin{tabular}{|c|c|c|c|c|c|c|}
\hline \multirow{2}{*}{\multicolumn{3}{|c|}{ Family members }} & \multicolumn{3}{|c|}{ Types of Works in Crop Field } & \multirow{3}{*}{$\begin{array}{c}\text { Total } \\
51 \\
\end{array}$} \\
\hline & & & \multirow{2}{*}{$\begin{array}{c}\text { All Works } \\
51\end{array}$} & \multirow{2}{*}{$\begin{array}{c}\text { Only in Raising and Harvesting } \\
-\end{array}$} & \multirow{2}{*}{$\begin{array}{c}\text { No work in agriculture } \\
- \\
\end{array}$} & \\
\hline \multirow{9}{*}{$\begin{array}{l}\text { Position in } \\
\text { Family }\end{array}$} & \multirow{3}{*}{ Father } & No. & & & & \\
\hline & & $\%$ & 100.0 & - & - & 100,0 \\
\hline & & Total \% & 25.2 & - & - & 25,2 \\
\hline & \multirow{3}{*}{ Spouse } & No. & 5 & 29 & 15 & 49 \\
\hline & & $\%$ & 10.2 & 59.2 & 30,6 & 100,0 \\
\hline & & Total \% & 2.5 & 14.4 & 7,4 & 24.3 \\
\hline & \multirow{3}{*}{ Child } & No. & 24 & 15 & 63 & 102 \\
\hline & & $\%$ & 23.5 & 14.7 & 61,8 & 100,0 \\
\hline & & Total \% & 11.9 & 7.4 & 31,2 & 50,5 \\
\hline \multirow{3}{*}{\multicolumn{2}{|c|}{ Total }} & No. & 80 & 44 & 78 & 202 \\
\hline & & $\%$ & 39.6 & 21.8 & 38.6 & 100,0 \\
\hline & & Total \% & 39.6 & 21.8 & 38.6 & 100,0 \\
\hline & & & $X^{2}: 143,907$ & P:0,00 Ho:Red $\Phi: 0,00$ & & \\
\hline
\end{tabular}

Ho: There is no relationship between individuals' roles in their families and what they do in agricultural production.

In order to examine the relationship between geographical features of the area and employment in agriculture, J48, which is a decision tree algorithm, was used. J48 Decision Tree algorithm is among the classification algorithms in the Weka ${ }^{1}$ statistics programme. The examination relationship between demographic features and agricultural employment by using the J48 algorithm yields the following classification learning and statistics (www.cs.waikato.ac.nz/ml/weka/). 
(Table 5.)

Gender $=$ Male

| Role in Family = Father: Can do all works in agriculture (51.0)

| Role in Family = Spouse: Can do all works in agriculture (0.0)

| Role in Family = Child

| | Social Security System Being Covered by = Retirement Fund: Can do all works in agriculture (1.0)

| $\mid$ Social Security System Being Covered by = Tradesmen: Bağ-Kur: Cannot work in agriculture (3.0)

| | Social Security System Being Covered by = SGK: Cannot work in agriculture (15.0/4.0)

| | Social Security System Being Covered by = None

| | | Age = 15-29: Can do all works in agriculture $(13.0 / 5.0)$

| | | Age = 30-49: Can do all works in agriculture (2.0)

| | Age $=50+$ : Can do all works in agriculture $(0.0)$

| | | Age = 7-14 : Cannot work in agriculture (6.0/1.0)

$|\quad|$ Social Security = Farmer Bağ-kur: Can do all works in agriculture (7.0)

Gender $=$ Female

| Role = Father: Cannot work in agriculture (0.0)

| $\quad$ Role $=$ Spouse

| $\mid$ Education = High School: Cannot work in agriculture (4.0/1.0)

| | Education = Secondary: Can work only in raising and harvesting (5.0/3.0)
| | Education = College-University: Cannot work in agriculture (2.0)

| | Education = Primary: Can work only in raising and harvesting (38.0/12.0)

| Role = Child: Cannot work in agriculture (55.0/14.0)

Table 5. J48 decision tree statistics by demographic characteristics

\begin{tabular}{|l|c|c|}
\hline Tests & No. & $\%$ \\
\hline Number of leaves & 16 & - \\
\hline Tree height & 22 & - \\
\hline Accurate Classification & 154 & 76,2 \\
\hline Kappa statistic & 0.63 & - \\
\hline Weighted Average & \multicolumn{2}{|c|}{0.76} \\
\hline True Positives & 0.12 \\
\hline False Positives & \multicolumn{2}{|c|}{0.77} \\
\hline Sensitivity & \multicolumn{2}{|c|}{0.76} \\
\hline Prevalence & \multicolumn{2}{|c|}{0.77} \\
\hline F-Score & 0.86 \\
\hline ROC Curve & \multicolumn{2}{|c|}{0.73} \\
\hline PRC Area & \multicolumn{2}{|c|}{} \\
\hline
\end{tabular}

\section{Confusion Matrix}

a b c

\begin{tabular}{lll|l}
27 & 15 & 2 & $\mathrm{a}=$ Only in raising and harvesting.
\end{tabular}

\begin{tabular}{lll|l}
13 & 61 & 4 & $\mathrm{~b}=$ No work in agriculture.
\end{tabular}

\begin{tabular}{lll|l}
6 & 8 & $66 \mid$ & $\mathrm{c}=$ All works.
\end{tabular}

Data obtained are given below in Figure 4 as decision tree visual 


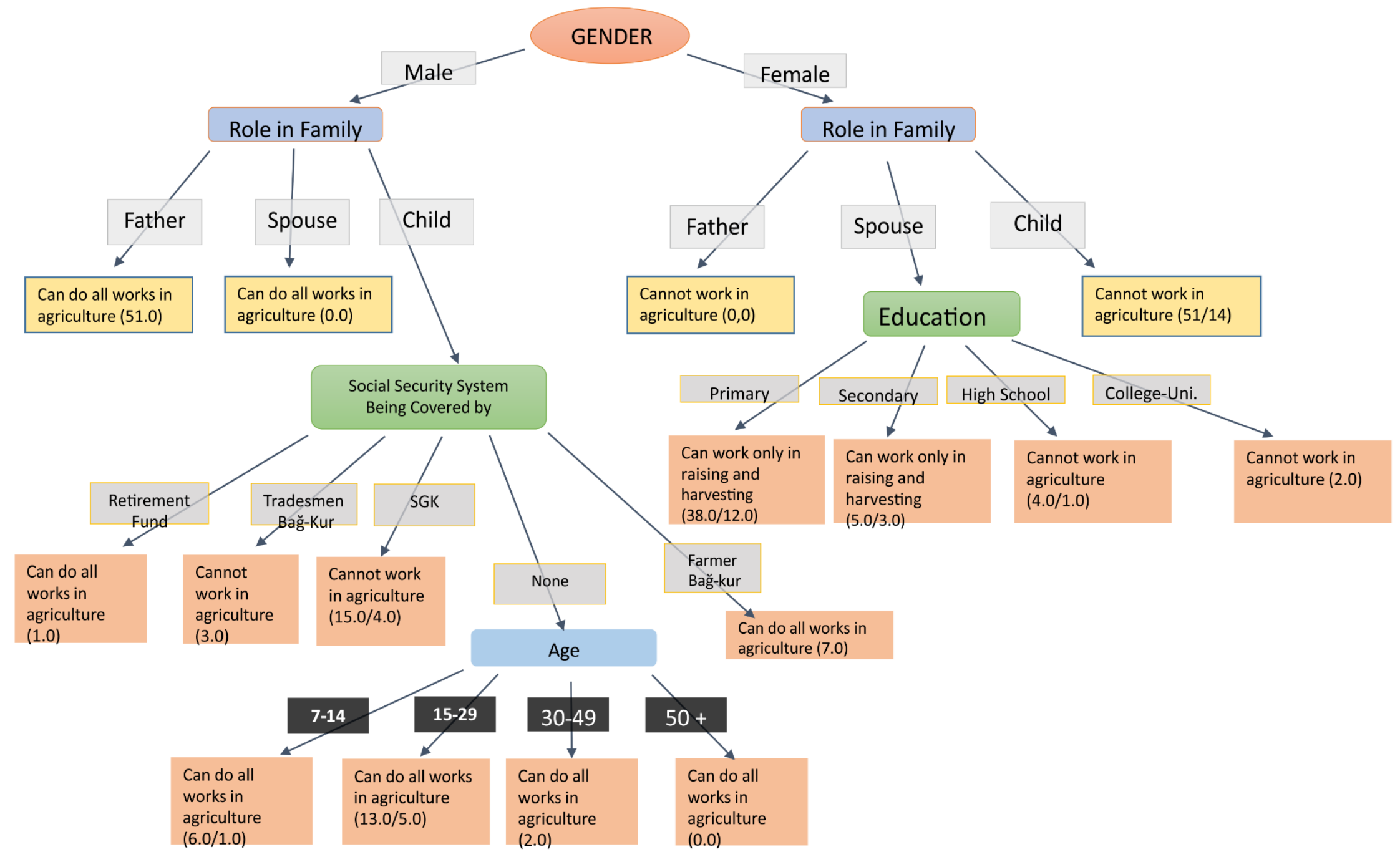

Figure 4. J.48 decision tree by demographic characteristics 
Table 6. Farmers' labour by months

\begin{tabular}{|c|c|c|c|c|c|c|c|c|c|c|c|c|c|c|c|c|c|c|c|}
\hline \multirow{2}{*}{ Months } & \multicolumn{4}{|c|}{ Family Labour (Wage/Day) } & \multicolumn{4}{|c|}{ Local Labour (Wage/Day) } & \multicolumn{4}{|c|}{ Seasonal Labour (Wage/Day) } & \multicolumn{4}{|c|}{ Foreign Labour (Wage/Day) } & \multicolumn{3}{|c|}{ Labour (Wage/Day) } \\
\hline & No. & $\overline{\mathrm{x}}$ & $\%$ & Total & No. & $\overline{\mathrm{x}}$ & $\%$ & Total & No. & $\overline{\mathrm{x}}$ & $\%$ & Total & No. & $\overline{\mathrm{x}}$ & $\%$ & Total & $\overline{\mathrm{x}}$ & Total & $\%$ \\
\hline March & 49 & 49.5 & 23.6 & 2425 & 19 & 122.9 & 22.7 & 2335 & 21 & 168.3 & 34.4 & 3535 & 13 & 151.9 & 19.2 & 1975 & 209.6 & 10.270 & 5.2 \\
\hline April & 51 & 49.2 & 18.2 & 2510 & 23 & 126.5 & 21.2 & 2910 & 30 & 175.8 & 38.3 & 5275 & 20 & 153.0 & 22.2 & 3060 & 269.7 & 13.755 & 7.0 \\
\hline May & 51 & 53.1 & 14.1 & 2710 & 25 & 129.8 & 16.9 & 3245 & 36 & 220.6 & 41.4 & 7940 & 28 & 188.0 & 27.5 & 5265 & 375.7 & 19.160 & 9.7 \\
\hline June & 51 & 61.4 & 13.4 & 3130 & 26 & 135.4 & 15.1 & 3520 & 38 & 264.1 & 43.0 & 10035 & 31 & 214.4 & 28.5 & 6645 & 457.5 & 23.330 & 11.8 \\
\hline July & 51 & 71.9 & 16.3 & 3665 & 22 & 131.4 & 12.9 & 2890 & 37 & 265.8 & 43.7 & 9835 & 22 & 277.0 & 27.1 & 6095 & 440.9 & 22.485 & 11.4 \\
\hline August & 51 & 66.7 & 16.3 & 3400 & 21 & 130.5 & 13.1 & 2740 & 36 & 258.5 & 44.5 & 9305 & 19 & 288.2 & 26.2 & 5475 & 410.2 & 20.920 & 10.6 \\
\hline September & 51 & 59.6 & 11.7 & 3040 & 24 & 141.0 & 13.1 & 3385 & 42 & 265.4 & 43.0 & 11145 & 34 & 245.6 & 32.2 & 8350 & 508.2 & 25.920 & 13.1 \\
\hline October & 51 & 57.3 & 11.4 & 2920 & 25 & 140.6 & 13.7 & 3515 & 47 & 229.9 & 42.1 & 10805 & 38 & 222.1 & 32.9 & 8440 & 503.5 & 25.680 & 13.0 \\
\hline November & 50 & 52.4 & 11.0 & 2620 & 21 & 177.1 & 15.7 & 3720 & 43 & 234.7 & 42.5 & 10090 & 36 & 203.5 & 30.8 & 7325 & 475.1 & 23.755 & 12.0 \\
\hline December & 37 & 46.6 & 14.0 & 1725 & 15 & 119.0 & 14.5 & 1785 & 22 & 268.4 & 47.9 & 5905 & 8 & 362.5 & 23.5 & 2900 & 332.8 & 12.315 & 6.2 \\
\hline Total & & & 14.3 & 28,145 & & & 15.2 & 30,045 & & & 42.4 & 83.870 & & & 28.1 & 55,530 & & 197.590 & 100.0 \\
\hline
\end{tabular}


It is observed that family labor falls short of what is needed for production. Hence, labor force recruited from labor force is recruited regardless of time and the nature of crops. The most important source in this is what is known as seasonal workers. Among with more recent migration movements, Syrian refugees too started to be a part of this labour force in Beypazarı too as in other parts of Turkey. At district level, those from the South-eastern part of the country are preferred more as labor force, while $28 \%$ in total are workers from other countries (Table 6).

Although all farmers are registered with the Farmer Registry System and they benefit from agricultural support schemes, it is observed that in relevant support schemes there is no warning, information, document, training or so to farmers in relation to work health and safety. Among support schemes, "Good Farming Practices" is the one with some weight of information and follow-up in regard to work health and safety, but only 6 out of 51 farmers have benefited from this support scheme.

\subsection{Farmers' Level of Perception and Information on Work Health and Safety}

When there is mention of the Law no. 6331 on Work Health and Safety, only $15.7 \%$ of responding farmers said they have full information about this law (8 out of 51). 21.6\% of farmers say they warn their employees to be careful about safety and health risks while working. Examining these warnings by their content, we find that $35.4 \%$ of them are related to the use of agricultural tools and machinery. Then comes the use of agricultural medicine and chemicals (24.0 \%) (Table 7). The interesting point here is that while more than half of farmers warn their employees in some way and about something, only $15.7 \%$ are fully informed about the legislation. In other words, here, there are normal suggestions as a part of working life rather than an act required by the law.

Table 7. Topics of warning by farmers to their employees *

\begin{tabular}{|l|c|c|}
\hline Themes of Warning & No. & \% \\
\hline Related to agricultural machinery and tools & 34 & 35.4 \\
\hline $\begin{array}{l}\text { Related to agricultural medicines and } \\
\text { chemicals }\end{array}$ & 23 & 24.0 \\
\hline General warnings about being attentive & 16 & 16.7 \\
\hline Related to electricity systems & 15 & 15.6 \\
\hline Related to water sources/sewage & 8 & 8.3 \\
\hline Total & $96 *$ & 100.0 \\
\hline
\end{tabular}

*: Total may be higher than 51 since more than one option may be chosen.

Farmers interviewed were posed the question; "What are the most important WHS precautions that come to your mind first?" In response to this question, $49 \%$ of farmers said "measures related to agricultural tools and machinery", followed by "medicine and chemicals used in agricultural activities" (41.2\%). The third is precautions related to electricity systems (by 39.2\% of farmers) (Table 8). Farmers responded to this question after options were read out to them. Their responses are not related to the level of information they have since they have no idea about which legislative arrangements their major warnings fit in.

Considering warnings to agricultural workers and measures applied by farmers, it is clear that the leading WHS-related one is " precautions related to agricultural tools and machinery. " It is inferred from the interviews that adoption of measures and precautions derive not from the information about the Law No. 6331 and necessity but from the concerns about keeping the activities going, some ethical motives and possible punitive sanctions that may be encountered if something adverse happens. There is, of course, the concern about any possible damage to tools and machinery.

Table 8. WSH measures applied by farmers

\begin{tabular}{|l|c|c|c|c|c|c|}
\hline \multirow{2}{*}{ Measures } & \multicolumn{2}{|c|}{ First } & \multicolumn{2}{|c|}{ Second } & \multicolumn{2}{|c|}{ Third } \\
\cline { 2 - 7 } & No. & $\%$ & No. & $\%$ & No. & \multicolumn{2}{c|}{$\%$} \\
\hline Related to agricultural machinery and tools & 25 & 49.0 & 15 & 29.4 & 7 & 13.7 \\
\hline Related to agricultural medicines and chemicals & 12 & 23.5 & 21 & 41.2 & 7 & 13.7 \\
\hline Related to electricity systems & 8 & 15.7 & 12 & 23.5 & 20 & 39.2 \\
\hline Related to water sources/sewage & 2 & 3.9 & 3 & 5.9 & 10 & 19.6 \\
\hline Related to dust and mould & - & - & - & - & 1 & 2.0 \\
\hline Related to wearing of protective clothes & 4 & 7.8 & - & - & 4 & 7.8 \\
\hline Related to safe transportation of workers & - & - & - & - & 2 & 3.9 \\
\hline Total & 51 & 100.0 & 51 & 100.0 & 51 & 100.0 \\
\hline
\end{tabular}


Table 9. Methods of risk identification used by farmers

\begin{tabular}{|c|c|c|c|c|c|c|c|c|c|c|c|c|}
\hline \multirow{3}{*}{ Methods of identification } & \multicolumn{12}{|c|}{ Priority assigned } \\
\hline & \multicolumn{2}{|c|}{1} & \multicolumn{2}{|c|}{2} & \multicolumn{2}{|c|}{3} & \multicolumn{2}{|c|}{4} & \multicolumn{2}{|c|}{5} & \multicolumn{2}{|c|}{6} \\
\hline & No. & $\%$ & No. & $\%$ & No. & $\%$ & No. & $\%$ & No. & $\%$ & No. & $\%$ \\
\hline $\begin{array}{l}\text { Machinery. Medication. etc. User } \\
\text { Guides }\end{array}$ & - & - & 2 & 3.9 & 7 & 14.9 & 12 & 35.3 & 4 & 19.0 & 2 & 18.2 \\
\hline Information from trainings & - & - & 4 & 7.8 & 3 & 6.4 & 3 & 8.8 & 4 & 19.0 & 1 & 9.1 \\
\hline $\begin{array}{l}\text { Personnel from District Agriculture } \\
\text { and Forestry Directorate }\end{array}$ & - & - & 1 & 2.0 & 8 & 17.0 & 3 & 8.8 & 2 & 9.5 & 4 & 36.4 \\
\hline Family environment and close circles & 48 & 94.1 & 3 & 5.9 & - & - & - & - & - & - & - & - \\
\hline Observations and experience & 3 & 5.9 & 35 & 68.6 & 5 & 10.6 & 2 & 5.9 & 3 & 14.3 & 1 & 9.1 \\
\hline Media & - & - & 2 & 3.9 & 14 & 29.8 & 3 & 8.8 & 4 & 19.0 & 2 & 18.2 \\
\hline Various user guides & - & - & 4 & 7.8 & 10 & 21.3 & 11 & 32.4 & 4 & 19.0 & 1 & 9.1 \\
\hline Total & 51 & 100.0 & 51 & 100.0 & 47 & 100.0 & 34 & 100.0 & 21 & 100.0 & 11 & 100.0 \\
\hline
\end{tabular}

\subsection{Health and Safety Related Practices and Sources of Information of Farmers}

Farmers were asked to identify WHS risks and to prioritize the options presented. $94.1 \%$ of farmers put in the first place the way of applying to " information by family elders and people in close environments. " (Table 9).

There is none among farmers who has his workers be regularly given health check-up by a health worker. Significant duties are assigned to Community Health Centres by the " Regulation on Community Health Centres (TSM) and Affiliated Units " and the " Prime Ministerial Circular for the Improvement of Working and Living Conditions of Seasonal Migrant Agricultural Workers. " However, it is observed that services envisaged by relevant legislation cannot find full reflection in practice, and provisions related to the health status of agricultural workers are not implemented effectively.

\subsection{Work Health and Safety Related Problems Faced by Farmers}

Farmers were asked about the problems they face in relation to WHS. The problem most frequently expressed by farmers (by 33.3\%) is the non-compliance of their workers to WHS-related warnings. This is of course a relative outlook since employers' adoption of relevant measures is as necessary as workers attentiveness. $23.5 \%$ of farmers say they face no problem in this respect, while $9.8 \%$ find agricultural workers untrained about WHS. There are some farmers who consider the language-communication problem of Syrian refugee workers as a WHS problem. These workers are employed informally and face problems in communicating their demands. To add, 3.9\% of farmers see the transportation of workers to places where they will work as a problem, while there is $2 \%$ mentioning problems in providing for toilet needs of workers. There is another $2 \%$ considering workers' inadvertency as a WHS problem.

\section{Conclusion}

Although this study covers only a specific field in agricultural activities, it can be said that it throws some light upon the state of work safety and health in other agricultural activities as well. There are very limited studies or almost none on work health and safety issues in Turkey that covers all risk factors. Given this, the present study gives important hints, besides open field culture, for other high-risk activities, such as stock-breeding, greenhouse culture, hazelnut, cotton farming, etc. in terms of health and safety for both employers and agricultural workers. Suggestions that can be drawn from such studies will be important, before anything else, with respect to efforts to minimize the risks and provide decent working and living conditions. Besides, there is also need for initiatives to include agricultural workers in social security schemes in the context of policies against informal employment. It appears that legislative arrangements remain insufficient without considering this more fundamental need.

Working conditions of agricultural workers in Turkey are not good. In addition to this, there should be other problems, such as poverty, low education level, poor housing conditions. Turkey's occupational health and safety of agricultural workers should do to remedy the existing problems in solving their economic problems and many other things. For this, it is important to pay attention to the following:

- Agricultural workforce statistics should be updated and constantly renewed. 
- Unregistered work in the agricultural sector should be controlled. A special registration and social security system should be developed, taking into account the specific conditions of agriculture.

- Due to the characteristics of the agricultural sector, different practices should be developed in WHS studies. For this reason, it is important to define family businesses in the social security system.

- Encouraging practices should be developed for the inclusion of agricultural workers in the social security system.

- All health personnel should be given training on working conditions and work accidents in agriculture.

- Awareness on the subject can be increased in different fields of books, magazines, print media, national media outlets and social media.

- Sample risk assessment studies for sub-activity areas of agriculture should be increased and sample practices should be disseminated. The standards of the studies should be established by collecting risk assessment studies in a database.

- Employers who include WHS practices in agriculture can be supported.

- Agricultural training and extension activities that will enable agricultural workers to gain a culture of occupational safety should be given importance and should be expanded.

- Agricultural extension activities, including occupational health and safety measures, should be increased and efforts should be focused on the process of adopting the relevant innovations.

- Developing infrastructure in rural areas is important for both rural development and human health. These aspects should also be taken into account in infrastructure studies.

- It is a fact that children spend time on the fields in dangerous environments in terms of WHS. Everyone should be careful so that children do not suffer from this situation.

- Measures should be taken to improve the economic conditions and wages of agricultural workers.

Given the importance of agriculture in Turkey, with its contribution to national economy, exports, employment and food security and safety, to have the Law No. 6331 on Work Health and Safety in Agriculture find its response in practice, it is necessary to ensure that rural people have their share from welfare and development and feel it. Since $85 \%$ of workforce in agricultural labour market is in informal employment, it is impossible for this law to be properly enforced. The enforcement requires, firstly, formal employment and inclusion of agricultural labour force in social security. Observations, conclusions and analyses included here hold true for all countries with a similar situation to Turkey.

\section{REFERENCES}

[1] Anonymous. 2003. Labour Code No. 4857, Official Gazette No. 25134 dated 10.06.2003

[2] Anonymous. 2005. Ministry of Agriculture and Rural Affairs in Turkey, Ankara

[3] Anonymous. 2010. Regulation on Employment Mediation in Agriculture, Official Gazette No. 27593 dated 27.05.2010

[4] Anonymous. 2012a. Work Health and Safety Law No. 6331, Official Gazette No. 28339 dated 30.06.2012

[5] Anonymous. 2012b. Communique on Work Health and Safety workplace hazard classification, Ministry of Labour and Social Security

[6] Anonymous. 2012c. Work Health and Safety Risk Assessment Regulation, Official Gazette No. 28512 dated 29.12.2012.

[7] Anonymous. 2013. Regulation on Training of Persons to be Employed in Hazardous and Very Hazardous Jobs, Official Gazette No. 28706 dated 13.07.2013, Ankara.

[8] Anonymous. 2015. Work Health and Safety Guide for Agricultural Areas, MoLSS General Directorate of Work Health and Safety.

[9] Anonymous. 2019. Bulletin of 2019 Cases of Workplace Homicide, Work Safety and Health Assembly. For access: http://isigmeclisi.org/20220-yasamak-ve-yasatmak-icin-dire necegiz-2019-yilinda-en-az-1736-isci-yasa

[10] Anonymous 2018b Data supplied by Beypazarı District Directorate of Ministry of Food, Agriculture and Animal Husbandry

[11] EUROSTAT, 2019. EU statistics website: ec.europa.eu/eur ostat

[12] Gülçubuk, B. and Yasan, Z. 2009. Rural Women's Labour as Gripped by Unemployment, Poverty and Migration, International Multidisciplinary Women Congress, 13-16 October, İzmir.

[13] Gülçubuk, B. 2017. Does the Law No. 6331 on Work Health and Safety mean anything to those working in agriculture? International Journal of Social Sciences and Education Research Volume: 3(2)

[14] Parça, H. 2018. “The Law on Work Health and Safety and its Applicability in Agriculture: A Study on Beypazar1 District of Ankara Province.” Ankara University, Institute of Sciences, Postgraduate Thesis (unprinted), Ankara.

[15] ILO, 2015. World Employment and Social Outlook Trends, ILO Publications, Geneva

[16] TÜİK 2013. Outcomes of Survey on Work Accidents and Occupational Health Problems

[17] TÜİK 2017a. Crop farming statistics

[18] TÜİK 2019. Turkish Statistical Institute 2019 Labour Force Statistics 